Original Articles

\title{
Chemotherapy-Induced Neutropenia in HIV Positive Patients with Lymphoma: Comparison of Pegfilgrastim with Daily Filgrastim Administration
}

Luciana Teofili ${ }^{1}$, Immacolata Izzi ${ }^{2}$, Eugenia Rosa Nuzzolo ${ }^{1}$, Giancarlo Scoppettuolo ${ }^{2}$, Lorenza Torti ${ }^{1}$, Marianna Rossi $^{2}$ and Katleen de Gaetano Donati ${ }^{2}$

${ }^{1}$ Department of Hematology and ${ }^{2}$ Department of Infectious Diseases, Catholic University of Rome, Italy

Correspondence to: Dr. Luciana Teofili, Hematology Department, Catholic University of Rome, Largo Gemelli 8 00168, Rome, Italy. Tel: +39-06-3015-4180, Fax: +39-06-3055153. Email: mailto:Iteofili@ @rm.unicatt.it

Competing interests: The authors have declared that no competing interests exist.

Published: October 3, 2012

Received: August 28, 2012

Accepted: September 20, 2012

Citation: Mediterr J Hematol Infect Dis 2012, 4(1): e2012062, DOI 10.4084/MJHID.2012.062

This article is available from: http://www.mjhid.org/article/view/10923

This is an Open Access article distributed under the terms of the Creative Commons Attribution License (http://creativecommons.org/licenses/by/2.0), which permits unrestricted use, distribution, and reproduction in any medium, provided the original work is properly cited.

Abstract. We retrospectively compared the incidence of neutropenia in two groups of HIV patients with lymphoma, who underwent chemotherapy supported by once-per-cycle administration of pegfilgrastim or by daily subcutaneous injection of filgrastim, respectively. Our findings indicate that pegfilgrastim and filgastrim produce similar results in preventing both neutropenia and febrile neutropenia.

Introduction. HIV infection leads to an increased risk of non-Hodgkin's lymphoma (NHL) and, to a minor extent, of Hodgkin's lymphoma (HL). The concomitant administration of highly active antiretroviral therapy (ART) to chemotherapy (CT) has greatly improved the outcome of these diseases. ${ }^{1}$ Furthermore, the management of CT induced neutropenia with recombinant human granulocyte-colony stimulating factors (G-CSFs, i.e. filgrastim and lenograstim) rendered feasible intensive $\mathrm{CT}$ regimens, including dose-dense CT or high dose CT, also in HIV positive patients. $^{2,3}$ A pegylated form of filgrastim is today available: actually, the addition of the polyethylene glycol molecule increases the serum half-life of filgrastim, resulting in its prolonged activity. ${ }^{3}$ Therefore, pegfilgrastim shows the advantage of a single injection per CT course as compared to repeated daily administration of filgrastim or lenograstim. The safety and efficacy of primary prophylaxis with all currently available G-CSFs in preventing febrile neutropenia (FN) and in supporting dose-dense therapy has been demonstrated in various malignancies and it is strongly recommended. ${ }^{4}$ However, a recent metaanalysis demonstrated that all currently available GCSFs significantly reduces the incidence of FN in comparison with patients not receiving growth factors, whereas pegfilgrastim in particular appeared the most effective one. ${ }^{4}$ If so, the superiority of pegfilgrastim should be even more evident in the setting of AIDS associated tumors, since these patients have a particular high infectious risk. Nevertheless, to our knowledge, the efficacy of pegylated and non pegylated G-CSFs in HIV positive patients has never been investigated. In this retrospective study we compared the efficacy of pegfilgrastim and filgastrim in preventing neutropenia and fever in a series of HIV patients treated at our institution.

Patients and Methods. The study population consisted of a series of $8 \mathrm{HIV}$ positive patients with diagnosis of 
HL $(n=4)$ and NHL $(n=4)$, consecutively observed at the department of Infectious Diseases of the Catholic University of Rome between October 2005 and July 2006. These patients received CT regimens supported by once-per-cycle administration of pegfilgrastim. As a control group, $13 \mathrm{HIV}$ positive patients (5 with HL and 8 with NHL) matched for age, diagnosis and CT, who had been previously followed at the same institution, were evaluated. All patients in the control group received CT supported by daily subcutaneous injection of filgrastim. Chemotherapy for $\mathrm{HL}$ consisted of $\mathrm{ABVD}^{7}$ in 3 patients with early stage HL, and of standard dose-BEACOPP ${ }^{8}$ or $\mathrm{EBVP}^{7}$ regimens in 6 patients with advanced stage-HL. Chemotherapy for NHL consisted of $\mathrm{CHOP}^{7}$ in 9 patients with diffuse large B-cell lymphoma and of Magrath protocol ${ }^{9}$ in 3 patients with Burkitt's lymphoma. Considering that all patients were treated before 2006, none of them received Rituximab in association with $\mathrm{CT}$. Both pegfilgrastim and filgrastim were administered 1 day after the completion of CT. In total, 23 courses of CT were evaluated in the pegfilgrastim group and 75 courses in the filgrastim group. The efficacy of pegfilgrastim and of filgrastim was assessed by evaluating the incidence of severe neutropenia (defined as neutrophil count less than $0.5 \times 10^{9} / \mathrm{L}$ ), the number of FN episodes and the number of positive blood cultures occurred among all recorded CT courses. Statistical comparison of continuous variables was performed by the Mann-Whitney U-test. Comparison of categorical variables was performed by chi-square statistic, using the Fisher's exact test. $\mathrm{P}$ values $<0.05$ were considered statistically significant.

Results. Clinical and laboratory findings of patients are shown in Table 1. No differences were found between pegfilgrastim or filgastrim groups of patients for sex and age distribution, stage of disease, Type of CT, and hematological parameters (Table 1). Moreover, the number of CD4+ cell count at diagnosis (evaluated as continuous variable) and the percentage of patients showing CD4+ cell count less than $200 / \mu \mathrm{L}$ were similar in both groups (Table 1). A similar proportion of patients in pegfilgrastim and filgrastim groups received ART in combination with CT (Table 1).

Table 1. Clinical and laboratory findings of HIV positive patients with Hodgkin lymphoma (HL) and non Hodgkin lymphoma (NHL), receiving pegfilgrastim or filgrastim, respectively.

\begin{tabular}{|c|c|c|c|}
\hline & Pegfilgrastim & Filgrastim & \\
\hline Patient $\mathbf{n}^{\circ}$ & 8 & 13 & $p$ \\
\hline NHL/HL & $4 / 4$ & $8 / 5$ & 0.67 \\
\hline Males/Females & $7 / 1$ & $8 / 5$ & 0.33 \\
\hline $\begin{array}{l}\text { Age(years): Mean } \\
\text { Median (Range) }\end{array}$ & $\begin{array}{c}45,2 \\
45,5(28-62)\end{array}$ & $\begin{array}{c}41,8 \\
44(28-51)\end{array}$ & 0.66 \\
\hline $\begin{array}{l}\text { WBC x } 10^{9} / \mathrm{L}: \text { Mean } \\
\text { Median (Range) }\end{array}$ & $\begin{array}{c}4.4 \\
4.5(3.6-5.1)\end{array}$ & $\begin{array}{c}4.7 \\
4.3(0.8-8.7)\end{array}$ & 0.84 \\
\hline $\begin{array}{l}\text { Hb g/dl: Mean } \\
\text { Median (Range) }\end{array}$ & $\begin{array}{c}11 \\
11,3(9-13,9)\end{array}$ & $\begin{array}{c}11,5 \\
11,1(9,3-13,3)\end{array}$ & 0.68 \\
\hline $\begin{array}{l}\text { PLT x 10'/L: Mean } \\
\text { Median (Range) }\end{array}$ & $\begin{array}{c}226 \\
257(110-297)\end{array}$ & $\begin{array}{c}147 \\
107(19-296)\end{array}$ & 0.48 \\
\hline $\begin{array}{l}\text { Stage } \\
\qquad \begin{array}{l}\text { I/ II } \\
\text { III/ IV }\end{array}\end{array}$ & $\begin{array}{l}1 \\
7\end{array}$ & $\begin{array}{c}2 \\
11\end{array}$ & 0.11 \\
\hline B symptoms (\%) & $6(75)$ & $10(77)$ & 1 \\
\hline $\begin{array}{l}\text { Chemotherapy } \\
\text { CHOP } \\
\text { Magrath } \\
\text { ABVD } \\
\text { BEACOPP } \\
\text { EBVP }\end{array}$ & $\begin{array}{l}3 \\
1 \\
1 \\
3 \\
-\end{array}$ & $\begin{array}{l}6 \\
2 \\
2 \\
1 \\
2\end{array}$ & 0.45 \\
\hline HAART (\%) & $7(87 \%)$ & $12(92 \%)$ & 1 \\
\hline CD4+ cells $<200 / \mu \mathrm{L}(\%)$ & $4(50)$ & $8(62)$ & 0.67 \\
\hline
\end{tabular}


Table 2. Incidence of severe neutropenia (neutrophils $<0,5 \times 10^{9} / \mathrm{L}$ ), febrile neutropenia and positive blood cultures in 23 chemotherapy courses supported by pegfilgrastim and in 75 chemotherapy courses supported by filgrastim.

Pegfilgrastim $\quad$ Filgrastim

\begin{tabular}{|c|c|c|c|c|c|}
\hline Total courses & & & & & $p$ \\
\hline & $n^{\circ}$ & $\%$ & $n^{\circ}$ & $\%$ & \\
\hline Grade IV neutropenia & & & & & \\
\hline n. of episodes & 8 & 35 & 32 & 43 & 0.63 \\
\hline days: median (range) & $5(2-7)$ & & $5(1-20)$ & & 0.80 \\
\hline Febrile neutropenia & 5 & 22 & 27 & 36 & 0.32 \\
\hline Positive blood cultures & 3 & (13) & 9 & 12 & 1 \\
\hline
\end{tabular}

Table 2 shows the efficacy end points observed in pegfilgrastim- as compared to filgrastim-supported CT courses. Severe neutropenia was observed in 8 out of the $23 \mathrm{CT}$ courses analyzed in the pegfilgrastim group, and in 32 out of the $75 \mathrm{CT}$ courses analyzed in the filgrastim group $(\mathrm{p}=0.63$, Table 2). The median duration of neutropenia was 5 days in both groups ( $\mathrm{p}=0.80$, Table 2). FN was recorded in 5 cases in pegfilgrastim group and in 27 cases in filgrastim group $(\mathrm{p}=0.14$, Table 2). Accordingly, no differences were found between pegfilgrastim and filgrastim-supported$\mathrm{CT}$ in the incidence of positive blood cultures ( $\mathrm{p}=1.00$, Table 2).

Discussion. To compare the efficay of pegylated and non-pegylated G-CSFs in the setting of HIV associated malignancies is an interesting issue to address. According to evidence-based clinical practice, primary prophylaxis with G-CSFs is recommended for CT regimens exceeding the $20 \%$ threshold of $\mathrm{FN}$ risk $^{4,10}$ and in dose-dense CT schedules. ${ }^{11,12}$ The existence of concomitant conditions predisposing to prolonged neutropenia, such as other myelotoxic therapies or bone marrow involvement by lymphoma cells, may help to identify which patients are most likely to benefit from prophylactic G-CSFs. ${ }^{410}$ In this respect, HIV positive persons undergoing CT for lymphoma represent a patients population at high risk for infection and FN. Actually, the diagnosis of lymphoma and HIV infection frequently occurs simultaneously ${ }^{1}$ and lymphoid tumors often arise in most immunocompromised HIV patients. ${ }^{13}$ In addition, the majority of HIV infected patients receives antiretroviral drugs and $\mathrm{CT}$ in combination: importantly, not only ART can have a direct hematologic toxicity ${ }^{14}$ but, in some instances, it can affect the metabolism of antiproliferative drugs so enhancing their bone marrow toxicity. ${ }^{15}$ Finally, lymphomas occurring in HIV positive patients, involve bone marrow more frequently than in general people. ${ }^{16}$ Our study shows that pegfilgrastim and filgrastim exhibit similar efficacy in controlling both CT-induced neutropenia and FN episodes in HIV positive patients with HL and NHL. Notwithstanding the worth of our findings is limited by the retrospective design of the study, they can suggest some considerations. While filgrastim and lenogratim are administered by a course of daily injections, pegfilgrastim posses the important advantage of once-per-cycle administration. This is an important aspect considering that several data from low level studies derived from audit data and clinical practice suggests that some patients receive suboptimal daily G-CSFs ${ }^{4}$ and the use of pegfilgrastim prevents this problem. Likewise, however, it is important to consider the cost of care is rising progressively, and that it is partly due to unnecessary use of health care resources. To this purpose, the American Society of Clinical Oncology has recently stated, among other opportunities to improve care and reduce costs, that GCSFs should be used only when the risk of FN, secondary to a recommended chemotherapy regimen is approximately $20 \%$ and equally effective treatment programs that do not require white cell stimulating factors are unavailable. ${ }^{17}$ In line with these recommendation, pegfilgrastim support should be mainly tailored to a cost-effective care provision. ${ }^{11,12}$ Nevertheless, in HIV positive patients, the simplified one-per cycle injection could result also in the reduced risk of infection by health care operators. This important topic should be considered an additional point to be clarified in studies performed on HIV infected patients. 


\section{References:}

1. Vaccher E, Spina M, Talamini R, Zanetti M, di Gennaro G, Nasti $\mathrm{G}$,et al. Improvement of systemic human immunodeficiency virusrelated non-Hodgkin lymphoma outcome in the era of highly active antiretroviral therapy (2003) Clin Infect Dis 37: 1556-64. http://dx.doi.org/10.1086/379517 PMid:14614680

2. Dunleavy K, Wilson WH. How I treat HIV-associated lymphoma. Blood 2012; 119:3245-55. http://dx.doi.org/10.1182/blood-201108-373738 PMid:22337719

3. Michieli M, Mazzucato M, Tirelli U, De Paoli P. Stem cell transplantation for lymphoma patients with HIV infection. Cell Transplant.
2011 ;
20:351-70. http://dx.doi.org/10.3727/096368910X528076 PMid:20875226

4. Lyman GH. Pegfilgrastim: a granulocyte colony-stimulating factor with sustained duration of action (2005). Expert Opin Biol Ther 5:1635-46. Review. http://dx.doi.org/10.1517/14712598.5.12.1635 PMid:16318427

5. Aapro MS, Bohlius J, Cameron DA, Dal Lago L, Donnelly JP, Kearney N, Lyman GH, Pettengell R, Tjan-Heijnen VC, Walewski J, Weber DC, Zielinski C; European Organisation for Research and Treatment of Cancer. 2010 update of EORTC guidelines for the use of granulocyte-colony stimulating factor to reduce the incidence of chemotherapy-induced febrile neutropenia in adult patients with lymphoproliferative disorders and solid tumours. Eur J Cancer. 2011;47:8-32. http://dx.doi.org/10.1016/j.ejca.2010.10.013 PMid:21095116

6. Cooper KL, Madan J, Whyte S, Stevenson MD, Akehurst RL Granulocyte colony-stimulating factors for febrile neutropenia prophylaxis following chemotherapy: systematic review and metaanalysis. BMC 2011; 11:404. http://dx.doi.org/10.1186/1471-2407-11-404 PMid:21943360 PMCid:3203098

7. Berretta M, Cinelli R, Martellotta F, Spina M, Vaccher E, Tirelli U. (2003) Therapeutic approaches to AIDS-related malignancies. Oncogene 22: 6646-59. http://dx.doi.org/10.1038/sj.onc.1206771 PMid:14528290

8. Hartmann P, Rehwald U, Salzberger B, Franzen C, Sieber M, Wohrmann A, et al. BEACOPP therapeutic regimen for patients with Hodgkin's disease and HIV infection. Ann Oncol 2003; 14: 1562-9. http://dx.doi.org/10.1093/annonc/mdg408 PMid:14504059

9. Mead GM, Sydes MR, Walewski J, Grigg A, Hatton CS, Pescosta $\mathrm{N}$, et al. An international evaluation of CODOX-M and CODOX$\mathrm{M}$ alternating with IVAC in adult Burkitt's lymphoma: results of
United Kingdom Lymphoma Group LY06 study. Ann Oncol. 2002; 13: 1264-74. http://dx.doi.org/10.1093/annonc/mdf253 PMid:12181251

10. Smith TJ, Khatcheressian J, Lyman GH, Ozer H, Armitage JO, Balducci L, et al. 2006 update of recommendations for the use of white blood cell growth factors: an evidence-based clinical practice guideline. J Clin Oncol 2006; 24: 3187-205. http://dx.doi.org/10.1200/JCO.2006.06.4451 PMid:16682719

11. Anderlini P, Champlin R. Use of filgrastim for stem cell mobilisation and transplantation in high-dose cancer chemotherapy. Drugs. 2002;62 Suppl 1:79-88. http://dx.doi.org/10.2165/00003495-200262001-00006 PMid:12479596

12. Kobbe G, Bruns I, Fenk R, Czibere A, Haas R. Pegfilgrastim for PBSC mobilization and autologous haematopoietic SCT. Bone Marrow Transplant. 2009;43:669-77. http://dx.doi.org/10.1038/bmt.2009.59 PMid:19308043

13. Grulich AE, Wan X, Law MG, Milliken ST, Lewis CR, Garsia RJ, et al. B-cell stimulation and prolonged immune deficiency are risk factors for non-Hodgkin's lymphoma in people with AIDS. AIDS 2000; 14: 133-40. http://dx.doi.org/10.1097/00002030-20000128000008 PMid:10708283

14. Pluda JM, Mitsuya H, Yarchoan R. Hematologic effects of AIDS therapies. Hematol Oncol Clin North Am 1991; 5: 229-48. PMid:1708759

15. Cingolani A, Torti L, Pinnetti C, de Gaetano Donati K, Murri R, Tacconelli E, Larocca LM, Teofili L. Detrimental clinical interaction between ritonavir-boosted protease inhibitors and vinblastine in HIV-infected patients with Hodgkin's lymphoma. AIDS. 2010; 24: 2408-12 PMid:20671541

16. Diamond C, Taylor TH, Im T, Anton-Culver H. Presentation and outcomes of systemic non-Hodgkin's lymphoma: a comparison between patients with acquired immunodeficiency syndrome (AIDS) treated with highly active antiretroviral therapy and patients without AIDS. Leuk Lymphoma 2006; 47: 1822-9. http://dx.doi.org/10.1080/10428190600658688

17. Schnipper LE, Smith TJ, Raghavan D, Blayney DW, Ganz PA, Mulvey TM, Wollins DS American Society of Clinical Oncology identifies five key opportunities to improve care and reduce costs: the top five list for oncology. J Clin Oncol. 2012;30:1715-24. http://dx.doi.org/10.1200/JCO.2012.42.8375 PMid:22493340 